OPEN ACCESS

Edited by:

Adi Behar.

Kimron Veterinary Institute, Israel

Reviewed by:

Bruno Gomez-Gil,

Consejo Nacional de Ciencia y Tecnología (CONACYT), Mexico

Kar Wai Hong,

University of Malaya, Malaysia

*Correspondence:

Malka Halpern

mhalpern@research.haifa.ac.il

Specialty section:

This article was submitted to

Coevolution,

a section of the journa

Frontiers in Ecology and Evolution

Received: 17 October 2021

Accepted: 12 January 2022

Published: 15 February 2022

Citation:

Sela $R$ and Halpern M (2022) The Chironomid Microbiome Plays a Role in Protecting Its Host From Toxicants.

Front. Ecol. Evol. 10:796830.

doi: $10.3389 /$ fevo.2022.796830

\section{The Chironomid Microbiome Plays a Role in Protecting Its Host From Toxicants}

\author{
Rotem Sela ${ }^{1}$ and Malka Halpern ${ }^{1,2 *}$ \\ 1 Department of Evolutionary and Environmental Biology, Faculty of Natural Sciences, University of Haifa, Haifa, Israel, \\ ${ }^{2}$ Department of Biology and Environment, Faculty of Natural Sciences, University of Haifa, Haifa, Israel
}

Organisms are assemblages of the host and their endogenous bacteria, which are defined as microbiomes. The host and its microbiome undergo a mutual evolutionary process to adapt to changes in the environment. Chironomids (Diptera; Chironomidae), are aquatic insects that grow and survive in polluted environments; however, the mechanisms that protect them under these conditions are not fully understood. Here we present evidence that the chironomids' microbiome enables them to survival in polluted environments. It has been demonstrated that about $40 \%$ of the microbiota that inhabit Chironomus transvaalensis egg masses and larvae has the potential to detoxify different toxicants. Metagenomic analysis of Chironomus ramosus larvae demonstrated the presence of genes in the insects' microbiome that can help the insects to survive in hostile environments. A set of experiments demonstrated that short exposure of C. transvaalensis larvae to metals significantly changed their microbiota composition in comparison to unexposed larvae. Another experiment, that followed Koch's postulates, demonstrated that disinfected $C$. transvaalensis larvae can survive toxic lead and chromium exposure when they are recolonized with bacteria that can detoxify these toxic metals. This accumulating research, points to the conclusion that the chironomid microbiome plays a role in protecting its host from toxicants.

Keywords: Chironomus, microbiome, microbiota, toxicants, holobiont

\section{INTRODUCTION}

All organisms host microbial assemblages that reside inside or on the surfaces of their body. These endogenous microorganisms, and the genes that are encoded in their chromosomes, are called the microbiome. Rosenberg and Zilber-Rosenberg (2013), proposed that an organism should be defined together with its microbiome as a holobiont. Moreover, they suggested that the host and the microbiota that inhabit it undergo joint evolutionary processes. One of these mutual evolutionary processes may be the adaptation to survive under hostile environments.

This review discusses how chironomids can survive and proliferate in stressful environments. We will highlight the chironomids' abilities to endure toxic heavy metals and demonstrate which microbes and genes may be involved in protecting the insects under stressful conditions. 


\section{CHIRONOMIDS}

Chironomids (Insecta; Diptera; Chironomidae; Chironomus spp.), are insects that undergo a full metamorphosis of four life stages: eggs, larvae, pupae (that develop in the water) and flying adults. In contrast to mosquitoes, chironomid adults do not feed or bite. They are globally distributed in various aquatic environments. It has been demonstrated that chironomids are natural hosts of V. cholerae and Aeromonas spp. (Broza and Halpern, 2001; Senderovich et al., 2008; Laviad and Halpern, 2016; Laviad-Shitrit et al., 2020).

The larvae of Chironomus spp. live at the bottom of freshwater habitats and form one of the most important functional groups in these ecosystems (Pinder, 1986). Aquatic sediments act as a sink for naturally occurring wastes and tend to be contaminated with toxic inorganic and organic compounds (Salmons et al., 1987). Chironomids live in almost every type of aquatic habitat and can tolerate extreme temperatures, $\mathrm{pH}$, salinity, depth, current velocity and even dehydration and ultraviolet (UV) and gamma radiations (Armitage et al., 1995; Datkhile et al., 2009a,b, 2015; Thorat and Nath, 2015). As a group, they are considered pollution tolerant and are known to thrive under adverse environmental conditions (Armitage et al., 1995; Wright and Burgin, 2009). They were found to dominate the fauna in polluted areas of streams, while in unpolluted sections of the same streams, they formed only a minor part of the fauna (Winner et al., 1980; Richardson and Kiffney, 2000; Watanabe et al., 2000). Tolerance of chironomids to pollution is well documented; however, the protective mechanisms they employ in contaminated and sometimes extreme environments are not fully understood.

\section{CHIRONOMIDS' MICROBIOME}

Several studies of Chironomus transvaalensis endogenous microbiota that used both culturable and unculturable methods identified a list of bacterial species that comprised C. transvaalensis microbiome. Among the microbiota that were identified from $C$. transvaalensis microbiome there were species from the following genera: Acidovorax, Acinetobacter, Aeromonas, Aquabacterium, Bacillus, Brevundimonas, Cetobacterium, Chryseobacterium, Citrobacter, Clostridium, Comamonas, Deinococcus, Delftia, Desulfovibrio, Exiguobacterium, Hydrogenophaga, Klebsiella, Oceanobacillus, Paracoccus, Pseudomonas, Rheinheimera, Shewanella, Stenotrophomonas, Vogesella, Yersinia, and Vibrio (Halpern et al., 2007a; Halpern, 2012; Senderovich and Halpern, 2012, 2013; Halpern and Senderovich, 2015; Sela and Halpern, 2019; Sela et al., 2020). Four isolates that were cultured and identified from Chironomus egg masses were identified as novel bacterial species: Oceanobacillus chironomi, Rheinheimera chironomi, Leucobacter chironomi, and Brachymonas chironomi (Halpern et al., 2007b, 2009a,b; Raats and Halpern, 2007).

Sela et al. (2020) found significant differences between the microbiota compositions of $C$. transvaalensis egg mass, larva, pupa and adult life stages. In each developmental stage, some genera were relatively dominant. In the egg mass stage, Hydrogenophaga, Deinococcus, Rheinheimera, and Aeromonas; for larvae, Cetobacterium, Vibrio, Aeromonas, and Acinetobacter; in pupae, Aeromonas, Aquabacterium, and Clostridium; and in adults, Aeromonas, Acinetobacter, and Vogesella. Interestingly, Aeromonas species were detected in all life stages of $C$. transvaalensis, suggesting that chironomids are reservoirs of Aeromonas species and they may serve as symbionts (Senderovich et al., 2008; Sela et al., 2020).

\section{EVIDENCE FOR THE PROTECTIVE ROLE OF THE ENDOGENOUS MICROBIOTA}

It has been demonstrated that chironomids' larvae microbiota may play a role in protecting their host from toxic metals (Senderovich and Halpern, 2012, 2013). Senderovich and Halpern (2012), isolated and identified different bacterial species from $C$. transvaalensis egg masses and larvae that were able to grow on selective media with high metal concentrations. The following bacterial species were isolated and identified from egg masses and demonstrated resistance to toxic metals; Citrobacter freundii; Citrobacter youngae; Enterobacter ludwigii were found to be resistant to copper while Bacillus horneckiae; Bacillus stratosphericus; Exiguobacterium indicum were identified as resistant to hexavalent chromium. Resistance to zinc was found in Pseudomonas geniculate and Stenotrophomonas maltophilia, while Yersinia nurmii and Exiguobacterium profundum demonstrated resistance to lead.

When Senderovich and Halpern (2013) analyzed the bacterial communities of $C$. transvaalensis egg masses and larvae they found that about 40 and $25 \%$ of all the genera that were identified in the egg masses and larval bacterial communities, respectively, may potentially have detoxifying abilities (Table 1). For example; Aeromonas species (3.3 and $1.6 \%$ prevalence in the larvae and the egg masses, respectively) were documented as species with the ability to detoxify toxic substances including heavy metals like $\mathrm{Pb}$, $\mathrm{Cr}, \mathrm{Cu}, \mathrm{Zn}$, and tributyltin (TBT) (Cruz et al., 2007; Senderovich and Halpern, 2012, 2013; Laviad and Halpern, 2016; Table 1). Further confirmation for the potential abilities of chironomid microbiota to detoxify a wide variety of toxicants was reported by Sela and Halpern (2019), who found that $43.3 \%$ of the genera that were identified from egg masses that were sampled from natural environments have the potential to detoxify or degrade different toxicants (Table 1; Sela and Halpern, 2019).

Leucobacter chironomi and Brachymonas chironomi (Halpern et al., 2009a,b), that were isolated from chironomid egg masses, were found to be resistant to heavy metals and other toxicants. The whole genome sequences of these two species (Genbank ID; ATXU00000000 and ARGE00000000, respectively) (Laviad et al., 2015a,b), revealed that their genomes include genes with the potential to detoxify toxic substances (Table 2).

A metagenomic study on Polypedilum vanderplanki (Chironomidae) larvae, that can endure desiccation, revealed that microbiota that inhabit this larval species can also withstand desiccation and radiation. However, it is not clear if these microorganisms that are resistant to desiccation 
TABLE 1 | A list of bacterial genera that were identified in C. transvaalensis egg masses, larvae or pupa and that have the potential to detoxify toxic substances.

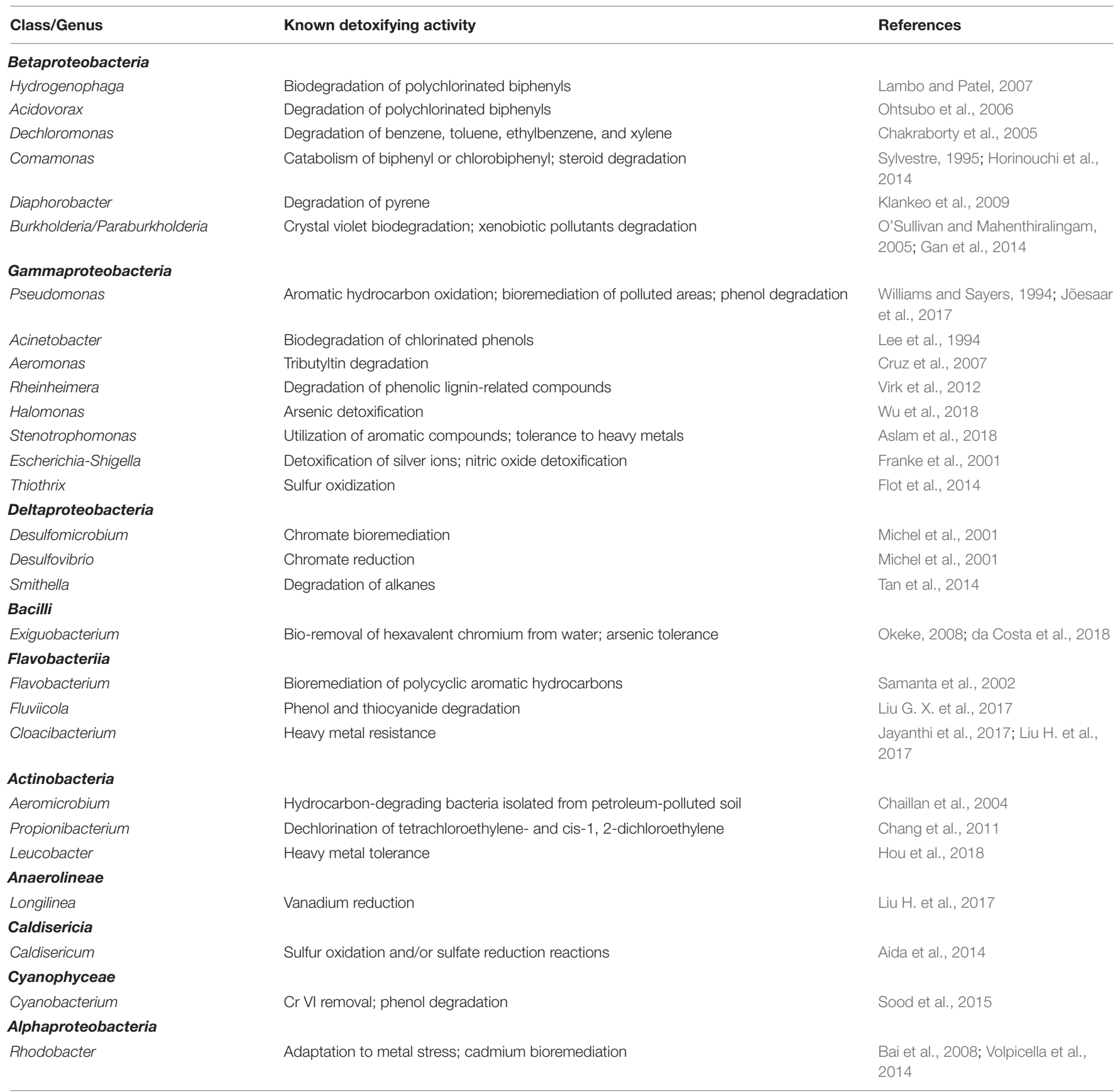

Data were summarized from Senderovich and Halpern (2013), Sela and Halpern (2019), and Sela et al. (2020).

Classes names are is in bold letters.

contribute to the resistance of the larvae to desiccation (Shaikhutdinov et al., 2020).

\section{METAGENOMIC STUDY OF Chironomus ramosus LARVAE}

Sela et al. (2021) analyzed three Chironomus ramosus larval microbiomes using metagenomics. Genes for detoxifying toxic metals like, copper ( $p c o D$; $\operatorname{cop} C$; $p c o C)$, Zinc ( $\mathrm{raP})$, lead (cadC; $s m t B$, and others, were detected in the metagenomic data. Furthermore, the presence of genes for resistance to antibiotics, UV radiation and others that were related to stress tolerance were also identified in the $C$. ramosus larval microbiome. Overall, 115,959 bacterial functional genes and 445 different pathways were detected in the $C$. ramosus larval microbiome (Sela et al., 2021).

One of the pathways that was detected in the larval microbiome was the toluene degradation pathway. Toluene, known to cause harm to the central nervous system 
TABLE 2 | A list of genes encoding enzymes with predicted resistance to toxic substances (data from Laviad et al., 2015a,b).

\begin{tabular}{|c|c|c|c|c|}
\hline Bacterial species & Arsenic resistance & Copper resistance & Other heavy metals & Organic solvents \\
\hline $\begin{array}{l}\text { Brachymonas } \\
\text { chironomi (Genbank } \\
\text { ID; ARGE00000000) }\end{array}$ & $\begin{array}{l}\text { ArsR; Arsenical resistance } \\
\text { operon trans-acting repressor, } \\
\text { ArsD; Arsenite efflux } \\
\text { ATP-binding protein, ArsA; A } \\
\text { hypothetical arsenic resistance } \\
\text { protein (ACR3 family). A gene } \\
\text { for arsenate reductase (ArsC } \\
\text { family) is present in a different } \\
\text { operon. }\end{array}$ & $\begin{array}{l}\text { Copper resistance protein D, } \\
\text { CopD; copper chaperone, } \\
\text { copper-resistance protein, } \\
\text { CopA; copper (or silver) } \\
\text { translocating P-type ATPase }\end{array}$ & & $\begin{array}{l}\text { Organic solvents; two genes } \\
\text { encoding the } \mathrm{ABC} \text {-type } \\
\text { transport system involved in } \\
\text { resistance to organic solvents }\end{array}$ \\
\hline $\begin{array}{l}\text { Leucobacter } \\
\text { chironomi (Genbank } \\
\text { ID; ATXU00000000) }\end{array}$ & $\begin{array}{l}\text { Arsenical resistance protein } \\
\text { (ArsB); arsenite efflux pump } \\
\text { ACR3 and related permeases. }\end{array}$ & $\begin{array}{l}\text { Copper chaperone; copper (or } \\
\text { silver) translocating P-type } \\
\text { ATPase }\end{array}$ & $\begin{array}{l}\text { Heavy metal-(Cd/Co/Hg/Pb/Zn)- } \\
\text { translocating P-type ATPase and } \\
\text { transcriptional regulator (ArsR } \\
\text { family) involved in stress- } \\
\text { response to heavy metal ions }\end{array}$ & \\
\hline
\end{tabular}

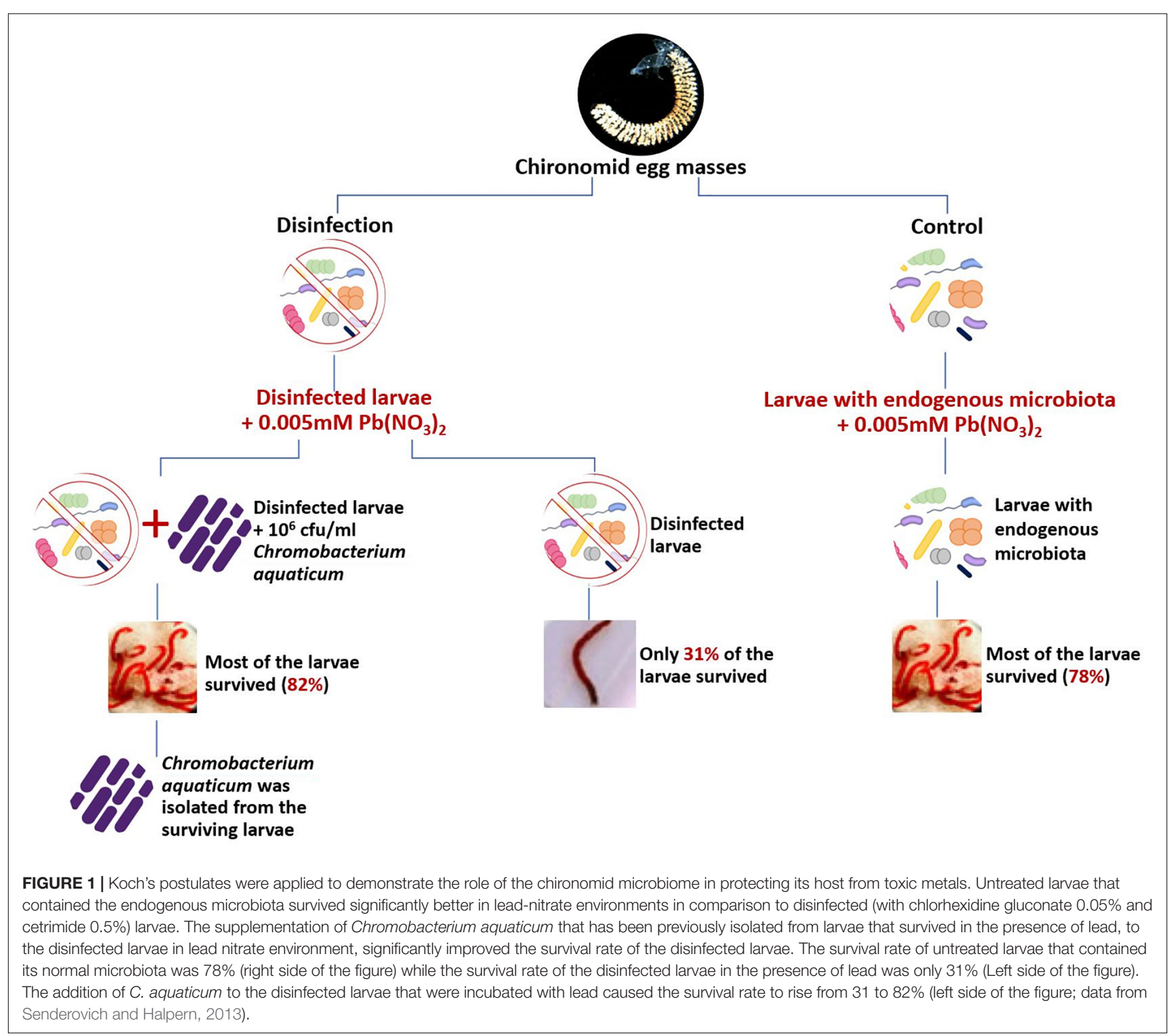


(Beller et al., 1992), is a waste product in different industrial processes and as such, is defined as an environmental contaminant (Heydarnezhad et al., 2018). It was found that species of Bacillus and Pseudomonas genera are able to degrade toluene and use it as their sole carbon source (Hamzah et al., 2011). These genera were identified in C. ramosus metagenomic analysis (Sela et al., 2021). Another relevant pathway identified is the atrazine degradation pathway (Sela et al., 2021). Atrazine is herbicide (Steinberg et al., 1995) extensively used to prevent the growth of wild plants in agriculture worldwide (Graymore et al., 2001). High concentrations of atrazine are detected in waterbody sediment (Graymore et al., 2001), where chironomids flourish. A variety of Gram-negative and Gram-positive bacterial genera were reported to degrade atrazine, including Pseudomonas (Mandelbaum et al., 1995), Rhodococcus (Behki et al., 1993), Acinetobacter (Mirgain et al., 1993), and Arthrobacter (Cai et al., 2003). All these genera were identified in the metagenomic data. Remarkably, high abundances of Acinetobacter and Pseudomonas were identified in C. ramosus larvae (Sela et al., 2021). These data provided evidence for the ability of the $C$. ramosus microbiome to protect the insect in hostile environments (Sela et al., 2021).

\section{EXPERIMENTAL PROOF OF THE ROLE OF THE MICROBIOTA IN PROTECTING CHIRONOMIDS}

To determine the role of chironomids' endogenous bacteria in the survival of chironomids in polluted environments, a bioassay based on Koch's postulates was performed (Figure 1; Senderovich and Halpern, 2013). In a preliminary experiment, they isolated two bacterial strains; Chromobacterium aquaticum and Shewanella decolorationis, that were identified from $C$. transvaalensis larvae that survived exposure to toxic lead and hexavalent chromium, respectively. These species were found to reduce $94 \%$ of toxic lead and $100 \%$ of hexavalent chromium, respectively. When these species were added to disinfected larvae that were incubated in lead or chromate containing environments, respectively, they significantly increased survival of the larvae in these toxic environments, compared to disinfected larvae without the addition of C. aquaticum and/or Sh. decolorationis. Thus, it has been demonstrated that these endogenous bacteria enable their host to survive in leadnitrate and hexavalent chromate containing environments (Senderovich and Halpern, 2013).

In another study, Laviad-Shitrit et al. (2021) examined larval survival and the change in the larval microbiota composition after 6 days of exposure to different concentrations of toxic copper and hexavalent chromium. A shift in the bacterial microbiota composition was observed in the larvae that were exposed to the different metals (Figure 2). Moreover, this shift was specific to the contaminating metal, suggesting that microbial composition changes-specifically proliferation of species with metal-reducing properties-in response to metal exposure may protect the larvae from the toxic metals. A proof for this hypothesis is the fact that there were no significant differences

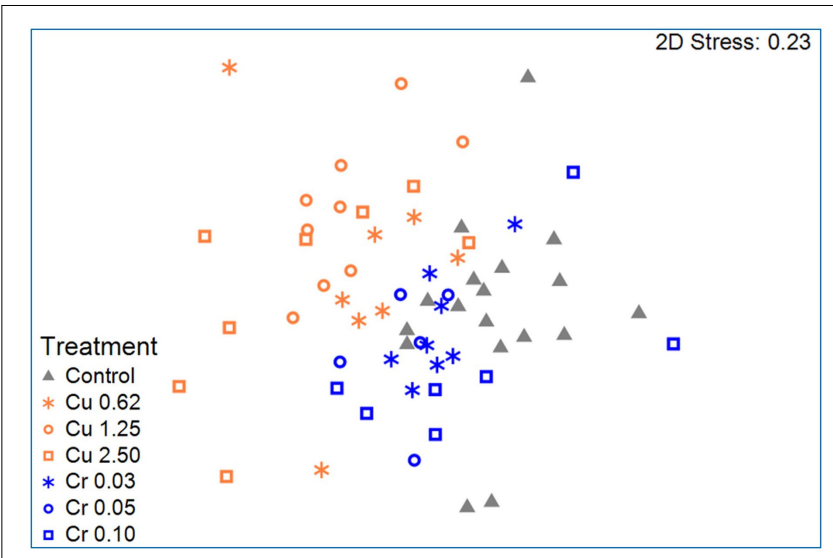

FIGURE 2 | An NMDS (non-metric multidimensional scaling) plot of the bacterial community composition of larvae that were exposed to copper or hexavalent chromium vs. the control (stress value $=0.23$ ). Significant differences were found between the bacterial communities of the control, the hexavalent chromium, and the copper treated larvae (ANOSIM: $R=0.476$, $p=0.001$ ). Adopted with permission from Laviad-Shitrit et al. (2021).

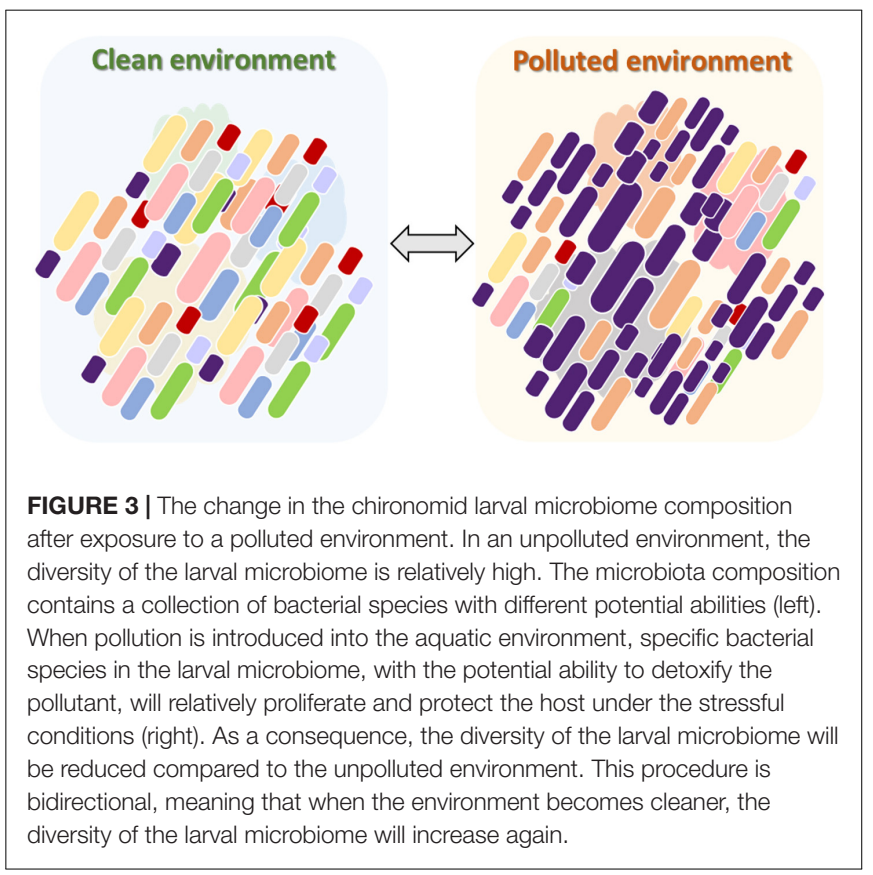

in the larval mortality between the control and the metal exposed larvae (Laviad-Shitrit et al., 2021; Figure 2). Furthermore, at the genus level, Yersinia and Acinetobacter abundances increased in the copper treated larvae, while Yersinia, Dysgonomonas, Delftia, and Enterococcus abundances increased after the larvae were exposed to hexavalent chromium, compared to the control. The change in the larval microbiota composition was rapid and metal-specific. Laviad-Shitrit et al. (2021) concluded that C. transvaalensis larvae host a bacterial consortium that proliferates differently and specifically under each environmental 
change and thus, protects the insect in various harsh conditions (Laviad-Shitrit et al., 2021).

\section{CONCLUDING REMARKS AND FUTURE DIRECTIONS}

The majority of the endogenous microbiota in chironomid egg masses and larvae is unculturable (Senderovich and Halpern, 2012). In this review we presented evidence that $C$. transvaalensis and $C$. ramosus microbiomes play a role in the survival of their host under toxic metal conditions. It is likely that the relative abundance of the different endogenous species that inhabit the insect changes according to environmental changes. As shown in this review, under high toxic metal concentrations, specific bacterial species with the potential ability to detoxify these metals will relatively proliferate and protect the host (Figure 3). More studies are needed to explore the mechanisms of this phenomenon in different Chironomus species and in

\section{REFERENCES}

Aida, A. A., Hatamoto, M., Yamamoto, M., Ono, S., Nakamura, A., Takahashi, M., et al. (2014). Molecular characterization of anaerobic sulfur-oxidizing microbial communities in up-flow anaerobic sludge blanket reactor treating municipal sewage. J. Biosci. Bioeng. 118, 540-545. doi: 10.1016/j.jbiosc.2014.04.011

Armitage, P., Cranston, P. S., Pinder, L. C. V., and Berg, M. B. (1995). The Chironomidae: Biology and Ecology of Non-Biting Midges. London: Chapman and Hall.

Aslam, F., Yasmin, A., and Thomas, T. (2018). Essential gene clusters identified in Stenotrophomonas MB339 for multiple metal/antibiotic resistance and xenobiotic degradation. Curr. Microbiol. 75, 1484-1492. doi: 10.1007/s00284018-1549-2

Bai, H.-J., Zhang, Z.-M., Yang, G.-E., and Li, B.-Z. (2008). Bioremediation of cadmium by growing Rhodobacter sphaeroides: kinetic characteristic and mechanism studies. Bioresour. Technol. 99, 7716-7722. doi: 10.1016/j.biortech. 2008.01.071

Behki, R., Topp, E., Dick, W., and Germon, P. (1993). Metabolism of the herbicide atrazine by Rhodococcus strains. Appl. Environ. Microbiol. 59, 1955-1959. doi: 10.1128/aem.59.6.1955-1959.1993

Beller, H. R., Grbić-Galić, D., and Reinhard, M. (1992). Microbial degradation of toluene under sulfate-reducing conditions and the influence of iron on the process. Appl. Environ. Microbiol. 58, 786-793. doi: 10.1128/AEM.58.3.786-793. 1992

Broza, M., and Halpern, M. (2001). Chironomid egg masses and Vibrio cholerae. Nature 412, 40-40. doi: 10.1038/35083691

Cai, B., Han, Y., Liu, B., Ren, Y., and Jiang, S. (2003). Isolation and characterization of an atrazine-degrading bacterium from industrial wastewater in China. Lett. Appl. Microbiol. 36, 272-276. doi: 10.1046/j.1472-765X.2003.01307.x

Chaillan, F., Le Flèche, A., Bury, E., Phantavong, Y., Grimont, P., Saliot, A., et al. (2004). Identification and biodegradation potential of tropical aerobic hydrocarbon-degrading microorganisms. Res. Microbiol. 155, 587-595. doi: 10. 1016/j.resmic.2004.04.006

Chakraborty, R., O'Connor, S. M., Chan, E., and Coates, J. D. (2005). Anaerobic degradation of benzene, toluene, ethylbenzene, and xylene compounds by Dechloromonas strain RCB. Appl. Environ. Microbiol. 71, 8649-8655. doi: 10. 1128/AEM.71.12.8649-8655.2005

Chang, Y.-C., Ikeutsu, K., Toyama, T., Choi, D., and Kikuchi, S. (2011). Isolation and characterization of tetrachloroethylene- and cis-1,2-dichloroethylenedechlorinating propionibacteria. J. Ind. Microbiol. Biotechnol. 38, 1667-1677. doi: 10.1007/s10295-011-0956-1

Cruz, A., Caetano, T., Suzuki, S., and Mendo, S. (2007). Aeromonas veronii, a tributyltin (TBT)-degrading bacterium isolated from an estuarine environment, different toxic and extreme environments. We assume that this phenomenon of the protective nature of the microbiota in the chironomid holobiont unit is probably only the tip of the iceberg. Further study of the role that microbiomes play in protecting different organisms is needed to understand the role of endogenous microbiota in protecting their hosts.

\section{AUTHOR CONTRIBUTIONS}

RS and MH wrote the manuscript. Both authors contributed to the article and approved the submitted version.

\section{FUNDING}

This work was supported by the United States-Israel Binational Science Foundation, BSF (grant no. 2015103) and the Joint UGC-ISF (4th cycle) Research Grant (grant no. 2728/17).

Ria de Aveiro in Portugal. Mar. Environ. Res. 64, 639-650. doi: 10.1016/j. marenvres.2007.06.006

da Costa, W. L. O., Araújo, C. L. A., Dias, L. M., Pereira, L. C. S., Alves, J. T. C., Araújo, F. A., et al. (2018). Functional annotation of hypothetical proteins from the Exiguobacterium antarcticum strain B7 reveals proteins involved in adaptation to extreme environments, including high arsenic resistance. PLoS One 13:e0198965. doi: 10.1371/journal.pone.0198965

Datkhile, K. D., Dongre, T. K., Mukhopadhyaya, R., and Nath, B. B. (2009a). Gamma radiation tolerance of a tropical species of midge, Chironomus ramosus Chaudhuri (Diptera: Chironomidae). Int. J. Radiat. Biol. 85, 495-503. doi: 10. 1080/09553000902883786

Datkhile, K. D., Mukhopadhyaya, R., Dongre, T. K., and Nath, B. B. (2009b). Increased level of superoxide dismutase (SOD) activity in larvae of Chironomus ramosus (Diptera: Chironomidae) subjected to ionizing radiation. Comp. Biochem. Physiol. C Toxicol. Pharmacol. 149, 500-506. doi: 10.1016/j.cbpc.2008. 11.003

Datkhile, K. D., Gaikwad, P. S., Ghaskadbi, S. S., Mukhopadhyaya, R., and Nath, B. B. (2015). Chironomus ramosus larvae exhibit DNA damage control in response to gamma radiation. Int. J. Radiat. Biol. 91, 742-748. doi: 10.3109/ 09553002.2015.1062572

Flot, J. F., Bauermeister, J., Brad, T., Hillebrand-Voiculescu, A., Sarbu, S. M., and Dattagupta, S. (2014). Niphargus - Thiothrix associations may be widespread in sulphidic groundwater ecosystems: evidence from southeastern Romania. Mol. Ecol. 23, 1405-1417. doi: 10.1111/mec.12461

Franke, S., Grass, G., and Nies, D. H. (2001). The product of the ybdE gene of the Escherichia coli chromosome is involved in detoxification of silver ions. Microbiology 147, 965-972. doi: 10.1099/00221287-147-4-965

Gan, L., Cheng, Y., Palanisami, T., Chen, Z., Megharaj, M., and Naidu, R. (2014). Pathways of reductive degradation of crystal violet in wastewater using freestrain Burkholderia vietnamiensis C09V. Environ. Sci. Pollut. Res. 21, 1033910348. doi: 10.1007/s11356-014-3037-y

Graymore, M., Stagnitti, F., and Allinson, G. (2001). Impacts of atrazine in aquatic ecosystems. Environ. Int. 26, 483-495. doi: 10.1016/S0160-4120(01)00031-9

Halpern, M. (2012). Chironomids and Vibrio cholerae. Beneficial Microorganisms in Multicellular Life Forms. Berlin: Springer.

Halpern, M., and Senderovich, Y. (2015). Chironomid microbiome. Microb. Ecol. 70, 1-8. doi: 10.1007/s00248-014-0536-9

Halpern, M., Landsberg, O., Raats, D., and Rosenberg, E. (2007a). Culturable and VBNC Vibrio cholerae: interactions with chironomid egg masses and their bacterial population. Microb. Ecol. 53, 285-293. doi: 10.1007/s00248-0069094-0

Halpern, M., Senderovich, Y., and Snir, S. (2007b). Rheinheimera chironomi sp. nov., isolated from a chironomid (Diptera; Chironomidae) egg 
mass. Int. J. Syst. Evol. Microbiol. 57, 1872-1875. doi: 10.1099/ijs.0. 64927-0

Halpern, M., Shaked, T., Pukall, R., and Schumann, P. (2009a). Leucobacter chironomi sp. nov., a chromate-resistant bacterium isolated from a chironomid egg mass. Int. J. Syst. Evol. Microbiol. 59, 665-670.

Halpern, M., Shakèd, T., and Schumann, P. (2009b). Brachymonas chironomi sp. nov., isolated from a chironomid egg mass, and emended description of the genus Brachymonas. Int. J. Syst. Evol. Microbiol. 59, 3025-3029.

Hamzah, A., Tavakoli, A., and Rabu, A. (2011). Detection of toluene degradation in bacteria isolated from oil contaminated soils. Sains Malays. 40, 1231-1235.

Heydarnezhad, F., Hoodaji, M., Shahriarinour, M., Tahmourespour, A., and Shariati, S. (2018). Optimizing toluene degradation by bacterial strain isolated from oil-polluted soils. Pol. J. Environ. Stud. 27, 655-663. doi: 10.15244/pjoes/ 75811

Horinouchi, M., Hayashi, T., Koshino, H., Malon, M., Hirota, H., and Kudo, T. (2014). Identification of $9 \alpha$-hydroxy-17-oxo-1,2,3,4,10,19-hexanorandrost6 -en-5-oic acid and $\beta$-oxidation products of the $\mathrm{C}$ - 17 side chain in cholic acid degradation by Comamonas testosteroni TA441. J. Steroid Biochem. Mol. Biol. 143, 306-322. doi: 10.1016/j.jsbmb.2014.04.014

Hou, S.-Y., Wang, F., Zhang, M.-Y., Cheng, J., and Zhang, Y.-X. (2018). A novel pigmented and heavy metal biosorptive bacterium, Leucobacter epilobiisoli sp. nov., isolated from rhizosphere soil of Epilobium hirsutum L. Antonie Van Leeuwenhoek 111, 1825-1833. doi: 10.1007/s10482-018-1071-3

Jayanthi, B., Emenike, C. U., Auta, S. H., Agamuthu, P., and Fauziah, S. H. (2017). Characterization of induced metal responses of bacteria isolates from active non-sanitary landfill in Malaysia. Int. Biodeterior. Biodegradation 119, 467-475. doi: 10.1016/j.ibiod.2016.10.053

Jõesaar, M., Viggor, S., Heinaru, E., Naanuri, E., Mehike, M., Leito, I., et al. (2017). Strategy of Pseudomonas pseudoalcaligenes C70 for effective degradation of phenol and salicylate. PLoS One 12:e0173180. doi: 10.1371/journal.pone. 0173180

Klankeo, P., Nopcharoenkul, W., and Pinyakong, O. (2009). Two novel pyrenedegrading Diaphorobacter sp. and Pseudoxanthomonas sp. isolated from soil. J. Biosci. Bioeng. 108, 488-495. doi: 10.1016/j.jbiosc.2009.05.016

Lambo, A. J., and Patel, T. R. (2007). Biodegradation of polychlorinated biphenyls in Aroclor 1232 and production of metabolites from 2,4,4' -trichlorobiphenyl at low temperature by psychrotolerant Hydrogenophaga sp. strain IA3-A. J. Appl. Microbiol. 102, 1318-1329. doi: 10.1111/j.1365-2672.2006.03268.x

Laviad, S., and Halpern, M. (2016). Chironomids' relationship with Aeromonas species. Front. Microbiol. 7:736. doi: 10.3389/fmicb.2016.00736

Laviad, S., Lapidus, A., Copeland, A., Reddy, T., Huntemann, M., Pati, A., et al. (2015a). High quality draft genome sequence of Leucobacter chironomi strain MM2LBT (DSM 19883T) isolated from a Chironomus sp. egg mass. Stand. Genom. Sci. 10:21. doi: 10.1186/s40793-015-0003-3

Laviad, S., Lapidus, A., Han, J., Haynes, M., Reddy, T., Huntemann, M., et al. (2015b). High quality draft genome sequence of Brachymonas chironomi AIMA4T (DSM 19884T) isolated from a Chironomus sp. egg mass. Stand. Genom. Sci. 10:29. doi: 10.1186/s40793-015-0010-4

Laviad-Shitrit, S., Sela, R., Thorat, L., Sharaby, Y., Izhaki, I., Nath, B. B., et al. (2020). Identification of chironomid species as natural reservoirs of toxigenic Vibrio cholerae strains with pandemic potential. PLoS Negl. Trop. Dis. 14:e0008959. doi: 10.1371/journal.pntd.0008959

Laviad-Shitrit, S., Sharaby, Y., Sela, R., Thorat, L., Nath, B. B., and Halpern, M. (2021). Copper and chromium exposure affect chironomid larval microbiota composition. Sci. Total Environ. 771:145330. doi: 10.1016/j.scitotenv.2021. 145330

Lee, C. M., Lu, C. J., and Chuang, M. S. (1994). Effects of immobilized cells on the biodegradation of chlorinated phenols. Water Sci. Technol. 30, 87-90. doi: 10.2166/wst.1994.0449

Liu, G. X., Wu, H.-Z., Sun, S.-L., Hu, X.-Y., Wu, X.-Y., Chen, H.-Y., et al. (2017). Aerobic degradation and microbial community succession of coking wastewater with municipal sludge. Huan Jing Ke Xue 38, 3807-3815. doi: 10. 13227/j.hjkx.201702146

Liu, H., Zhang, B., Yuan, H., Cheng, Y., Wang, S., and He, Z. (2017). Microbial reduction of vanadium (V) in groundwater: interactions with coexisting common electron acceptors and analysis of microbial community. Environ. Pollut. 231, 1362-1369. doi: 10.1016/j.envpol.2017.08.111
Mandelbaum, R. T., Allan, D. L., and Wackett, L. P. (1995). Isolation and characterization of a Pseudomonas sp. that mineralizes the s-triazine herbicide atrazine. Appl. Environ. Microbiol. 61, 1451-1457. doi: 10.1128/aem.61.4.14511457.1995

Michel, C., Brugna, M., Aubert, C., Bernadac, A., and Bruschi, M. (2001). Enzymatic reduction of chromate: comparative studies using sulfate-reducing bacteria. Key role of polyheme cytochromes c and hydrogenases. Appl. Microbiol. Biotechnol. 55, 95-100. doi: 10.1007/s002530000467

Mirgain, I., Green, G. A., and Monteil, H. (1993). Degradation of atrazine in laboratory microcosms: isolation and identification of the biodegrading bacteria. Environ. Toxicol. Chem. 12, 1627-1634. doi: 10.1002/etc.5620120911

O'Sullivan, L. A., and Mahenthiralingam, E. (2005). Biotechnological potential within the genus Burkholderia. Lett. Appl. Microbiol. 41, 8-11. doi: 10.1111/j. 1472-765X.2005.01758.x

Ohtsubo, Y., Goto, H., Nagata, Y., Kudo, T., and Tsuda, M. (2006). Identification of a response regulator gene for catabolite control from a PCB-degrading betaproteobacteria, Acidovorax sp. KKS102. Mol. Microbiol. 60, 1563-1575. doi: 10.1111/j.1365-2958.2006.05197.x

Okeke, B. C. (2008). Bioremoval of hexavalent chromium from water by a salt tolerant bacterium, Exiguobacterium sp. GS1. J. Ind. Microbiol. Biotechnol. 35, 1571-1579. doi: 10.1007/s10295-008-0399-5

Pinder, L. C. V. (1986). Biology of freshwater Chironomidae. Annu. Rev. Entomol. 31, 1-23. doi: 10.1146/annurev.en.31.010186.000245

Raats, D., and Halpern, M. (2007). Oceanobacillus chironomi sp. nov., a halotolerant and facultative alkaliphilic species isolated from a chironomid egg mass. Int. J. Syst. Evol. Microbiol. 57, 255-259. doi: 10.1099/ijs.0.64502-0

Richardson, J. S., and Kiffney, P. M. (2000). Responses of a macroinvertebrate community from a pristine, southern British columbia, Canada, stream to metals in experimental mesocosms. Environ. Toxicol. Chem. 19, 736-743. doi: 10.1002/etc.5620190328

Rosenberg, E., and Zilber-Rosenberg, I. (2013). The Hologenome Concept: Human, Animal and Plant Microbiota. New York, NY: Springer. doi: 10.1007/978-3319-04241-1

Salmons, W., de Rooij, N., Kerdijk, H., and Bril, J. (1987). Sediments as a source for contaminants? Hydrobiology 149, 13-30. doi: 10.1007/BF00048643

Samanta, S. K., Singh, O. V., and Jain, R. K. (2002). Polycyclic aromatic hydrocarbons: environmental pollution and bioremediation. Trends Biotechnol. 20, 243-248. doi: 10.1016/S0167-7799(02)01943-1

Sela, R., and Halpern, M. (2019). Seasonal dynamics of Chironomus transvaalensis populations and the microbial community composition of their egg masses. FEMS Microbiol. Lett. 366:fnaa008. doi: 10.1093/femsle/fnaa008

Sela, R., Laviad-Shitrit, S., and Halpern, M. (2020). Changes in microbiota composition along the metamorphosis developmental stages of Chironomus transvaalensis. Front. Microbiol. 11:586678. doi: 10.3389/fmicb.2020.586678

Sela, R., Laviad-Shitrit, S., Thorat, L., Nath, B. B., and Halpern, M. (2021). Chironomus ramosus larval microbiome composition provides evidence for the presence of detoxifying enzymes. Microorganisms 9:1571. doi: 10.3390/ microorganisms 9081571

Senderovich, Y., and Halpern, M. (2012). Bacterial community composition associated with chironomid egg masses. J. Insect Sci. 12, 1-14. doi: 10.1673/031. 012.14901

Senderovich, Y., and Halpern, M. (2013). The protective role of endogenous bacterial communities in chironomid egg masses and larvae. ISME J. 7, 21472158. doi: 10.1038/ismej.2013.100

Senderovich, Y., Gershtein, Y., Halewa, E., and Halpern, M. (2008). Vibrio cholerae and Aeromonas: do they share a mutual host? ISME J. 2, 276-283. doi: 10.1038/ ismej.2007.114

Shaikhutdinov, N., Gogoleva, N., Gusev, O., and Shagimardanova, E. (2020). Microbiota composition data of imago and larval stage of the anhydrobiotic midge. Data Brief 33:106527. doi: 10.1016/j.dib.2020.106527

Sood, A., Renuka, N., Prasanna, R., and Ahluwalia, A. S. (2015). "Cyanobacteria as potential options for wastewater treatment," in Phytoremediation, eds A. A. Ansari, S. S. Gill, R. Gill, G. R. Lanza, and L. Newman (Cham: Springer), 83-93. doi: 10.1007/978-3-319-10969-5_8

Steinberg, C. E. W., Lorenz, R., and Spieser, O. H. (1995). Effects of atrazine on swimming behavior of zebrafish, Brachydanio rerio. Water Res. 29, 981-985. doi: 10.1016/0043-1354(94)00217-U 
Sylvestre, M. (1995). Biphenyl/Chlorobiphenyls catabolic pathway of Comamonas testosteroni B-356: prospect for use in bioremediation. Int. Biodeterior. Biodegradation 35, 189-211. doi: 10.1016/0964-8305(95)00034-3

Tan, B., Nesbø, C., and Foght, J. (2014). Re-analysis of omics data indicates Smithella may degrade alkanes by addition to fumarate under methanogenic conditions. ISME J. 8, 2353-2356. doi: 10.1038/ismej.2014.87

Thorat, L., and Nath, B. B. (2015). Tolerance to desiccation stress in Chironomus ramosus through plasticity in homeostatic control. Eur. J. Environ. Sci. 5, 86-91.

Virk, A. P., Capalash, N., and Sharma, P. (2012). An alkalophilic laccase from Rheinheimera species isolate: production and biobleaching of kraft pulp. Biotechnol. Prog. 28, 1426-1431. doi: 10.1002/btpr.1619

Volpicella, M., Costanza, A., Palumbo, O., Italiano, F., Claudia, L., Placido, A., et al. (2014). Rhodobacter sphaeroides adaptation to high concentrations of cobalt ions requires energetic metabolism changes. FEMS Microbiol. Ecol. 88, 345-357.

Watanabe, N., Harada, S., and Komai, Y. (2000). Long-term recovery from mine drainage disturbance of a macroinvertebrate community in the Ichi-kawa River, Japan. Hydrobiologia 429, 171-180. doi: 10.1023/A:1004027201667

Williams, P. A., and Sayers, J. R. (1994). The evolution of pathways for aromatic hydrocarbon oxidation in Pseudomonas. Biodegradation 5, 195-217.

Winner, R., Bossel, M., and Farrel, M. (1980). Insect community structure as an index of heavy-metal pollution in lotic ecosystems. Can. J. Fish. Aquat. Sci. 37, 647-655. doi: 10.1139/f80-081
Wright, I. A., and Burgin, S. (2009). Effects of organic and heavy metal pollution on chironomids within a pristine upland catchment. Hydrobiologia 635:15. doi: 10.1007/s10750-009-9857-y

Wu, S., Wang, L., Gan, R., Tong, T., Bian, H., Li, Z., et al. (2018). Signature arsenic detoxification pathways in Halomonas sp. strain GFAJ-1. mBio 9:e00515-18. doi: $10.1128 / \mathrm{mBio} .00515-18$

Conflict of Interest: The authors declare that the research was conducted in the absence of any commercial or financial relationships that could be construed as a potential conflict of interest.

Publisher's Note: All claims expressed in this article are solely those of the authors and do not necessarily represent those of their affiliated organizations, or those of the publisher, the editors and the reviewers. Any product that may be evaluated in this article, or claim that may be made by its manufacturer, is not guaranteed or endorsed by the publisher.

Copyright (c) 2022 Sela and Halpern. This is an open-access article distributed under the terms of the Creative Commons Attribution License (CC BY). The use, distribution or reproduction in other forums is permitted, provided the original author(s) and the copyright owner(s) are credited and that the original publication in this journal is cited, in accordance with accepted academic practice. No use, distribution or reproduction is permitted which does not comply with these terms. 